\title{
Divine Winds and Human Waves: The Kamikaze's Rise Over the Course of Japanese History
}

\author{
ShaoYuan Su${ }^{1}$ and Andrew R. Wilson ${ }^{1}$ \\ ${ }^{1}$ Cary Academy, Cary, NC, USA \\ DOI: https://doi.org/10.47611/jsrhs.v10i2.1456
}

\section{ABSTRACT}

Japan's World War II Kamikaze-attack strategy has become common knowledge to almost all Americans, with many sharing a preconception of fanatical and desperate Japanese pilots willfully crashing into American ships; however, this essay will demonstrate that the progression to suicidal aircraft attacks evolved gradually over the course of Japanese history. The roots of Kamikaze extend as far back as the Mongol Invasions of Japan, and it rose to prominence first during the Meiji Restoration and then with Nogi's actions during the Russo-Japanese war. This paper will trace the progression of Kamikaze throughout Japanese history to explain how a sequence of events, some directed by chance and others directed by commanders, culminated in Japan's purpose-built, manned flying bombs that emerge in the Second World War. Understanding the historical context of Kamikaze and its logical evolution over time will help dispel the commonly held preconception of the singularly devoted but maniacally deranged Japanese soldier.

\section{Introduction}

On April 6, 1945, the peaceful blue skies above the Japanese island of Okinawa suddenly filled with hundreds of Japanese Kamikaze aircraft speeding towards the U.S. Fifth Fleet stationed offshore in support of the American ground offensive. The Fifth Fleet had faced sporadic Kamikaze attacks, most notably at the battle of Leyte Gulf, but this was the first large-scale coordinated offensive launched by the Japanese (Gill). Waves upon waves of Japanese fighters overwhelmed the anti-aircraft defenses of the escort carriers, destroyers, and minesweepers. During the next two days, over 350 enemy planes wreak absolute havoc on the Fifth Fleet. This Kamikaze spree, dwarfing any before or since killed over 5,000 U.S sailors and wounded another 5,000 by late June 1945, at the expense of 2,000 Japanese pilots ("John Chapman and the Kamikaze Attack"). Furthermore, they sank a total of 36 U.S. ships and damaged almost 400 others (Ibid). These attacks on the Fifth Fleet at Okinawa represented the greatest concentration of losses since Pearl Harbor for the U.S Navy ("Battle of Okinawa").

Even though most people associate the term Kamikaze with the World War Two Japanese airborne suicide attacks, this phenomenon and ideology of heroic death actually originated with the attempted Mongol invasion of Japan in 1281 and has subsequently evolved through Japanese culture and their military for centuries (Delgado 41). The creation of war machines specifically designed to conduct suicide missions and extensive Kamikaze attacks as a deliberate military strategy directly resulted from Japan's unique historical decisions since the late 19th century, culminating in the large-scale suicide attacks in the last few desperate months of World War Two. This essay will examine the historical origins of these Japanese suicide attacks, how the Japanese attitude towards them shifts during that war, and how these factors ultimately led Japan to create war machines specifically designed to facilitate these suicide missions. 


\section{Background}

The popular imagination mistakenly stereotypes Japanese military strategy as reliant on a certain crazed fanaticism. Many people think that the use of Kamikaze tactics are exclusive to the Japanese, but they fail to consider how many other powerful militaries have also resorted to suicide tactics in times of desperation. For instance, after Hitler's Blitzkrieg significantly damaged the Soviet Air Force's capabilities as a result of the German push towards Moscow, Soviet authorities resorted to taran tactics, or aerial rammings in which one aircraft crashes into another mid-air, to slow the German offensive (Quinlivan 49). Over the course of World War Two, a total of 430 cases of taran maneuvers were recorded (Ibid 55). The Nazis had also experimented with several prototypes of manned flying bombs, including the Reichenberg bomb, which carried a 1,900-pound warhead and could travel at almost 450 miles per hour, fast enough to outrun any piston-engine fighter at the time (Gnam). Unfortunately, in the 21st century, we are all too familiar with sporadic suicide bombings and attacks, but at the time this tactic was shocking. Although the Russians and Germans experimented with the strategy, the scale and lethality of its use by the Japanese was unprecedented and, even today, many link the Kamikaze phenomenon to Japan's national psyche.

Suicide attacks are tied so closely with the Japanese national psyche purely because the scale of Japanese attacks has been unparalleled by any other country since World War Two. The Japanese also took the concept of suicide attacks further, effectively creating a variation for every single branch of their military. The Ohka, a 2,646pound rocket-propelled bomb manned by a minimally trained pilot and capable of reaching 750 miles per hour, was actually deployed over a dozen times against American ships ("Yokosuka MXY-7 Ohka 11"). Additionally, the Kaiten, a manned torpedo three times the size of a conventional munition, was fitted with a periscope and steering controls, which allowed the pilot to ram it straight into the hull of an American warship (Cox). These manned missiles were additionally complemented by Banzai charges, where waves of Japanese troops launched assaults on hardened enemy positions; for example, during the Battle of Attu, 2,351 Japanese troops launched a massive Banzai charge against American troops guarding artillery positions in Massacre Bay, resulting in only twenty-eight Japanese soldiers surviving their suicidal charge despite having little to no effect on the outcome of the battle (Garfield 292-297). As a result of Japan's suicide tactics in this war, a preconception exists that suicide attacks and heroic death was at the heart of Japan's military culture, not just in World War Two but throughout history. But where did the concept of Kamikaze originate and how did it evolve into the actions we see on April 6, 1945?

\section{Origins of the Kamikaze - The Mongol Invasions of 1274 and 1281}

The term Kamikaze is thought to have been coined in 1274 CE in Japan, amidst the first attempted Mongol invasion. Kublai Khan, the grandson of Genghis Khan and Mongol Emperor of China's Yuan Dynasty, exhibited an interest in Japan and demanded tribute from the small island nation as early as $1268 \mathrm{CE}$, threatening military action if his demands were not satisfied (Cartwright). Kublai Khan may have had several motivations to Japan's conquest: the isolated island had a long-standing reputation as the "Island of Gold," a belief that Marco Polo recorded from his travels to China, and also because Japan's conquest would nullify the constant threats to Mongol shipping from Japanese Wako pirates (Ibid). Whatever his true intention, Kublai Khan amassed a fleet of 800 ships carrying upwards of 40,000 men to launch an invasion against the Japanese as a result of their "diplomatic silence" regarding the tribute (Neumann 1168). The Mongol invaders were superior to the Japanese defenders in almost every way. Not only did the former wield more advanced weaponry, including armour-piercing crossbows and gunpowder-grenade catapults, but they also had superior tactics, relying on massive cavalry charges and boasting larger troop numbers to overwhelm the Japanese defenders (Cartwright). On November 15, the 40,000-strong Mongol invading force established a beachhead at Hakata Bay on the ten-kilometer stretch of shoreline in the Eastern part of mainland Japan (Ibid). In contrast, a paltry defense force of only 4,000-6,000 men greeted the Mongol invaders (Turnbull and Hook 32). Due to their 
superior weaponry and numbers, the Mongols had reached the walls of Dazaifu, the provincial capital, in just a few days (Adams 97).

Outnumbered and armed with inferior weaponry, the Japanese faced a dire predicament. Furthermore, with no reinforcements being sent their way, victory seemed hopeless for them. Unexpectedly, however, the tide turned overwhelmingly in Japan's favor when a massive typhoon struck the Mongol ships anchored at Hakata Bay, killing one-third of the entire invasion force and severely damaging their fleet, forcing the survivors to retreat to China (Turnbull 66). Japanese mythology at the time attributed this natural weather occurrence - that just so happened to devastate the invading Mongol fleet - to Raijin, the Japanese god of thunder, lightning, and storms in the Shinto Religion (Holloway). The sudden and unexpected Japanese victory caused many to believe that this storm was an act of divine intervention; hence, they coined the term Kamikaze (神風 in Japanese), literally meaning “Divine Wind” (Powell). The Japanese belief that the divine intervention played a vital role in saving their Empire was further reinforced by another Mongol invasion, also hampered by weather seven years later in 1281 (Delgado 37). These events encouraged the lasting belief that, whenever defeat seems imminent, a sudden, destructive force-the Divine Wind, or Kamikaze_-would save the chosen island nation by overwhelming Japan's adversaries (Turnbull 72).

\section{The Western Origins of the Bushido Code - The 1868 Meiji Restoration}

However, faith in mythology will not win wars. Japan's martial ideology centered around its ancient Samurai code, which an evolving government under outside pressure modified in response to contact with the Western world. It was during the 1868 Meiji Restoration, when foreign encroachment forced Japan to transform itself from a feudal Shogunate (a military dictatorship) to a constitutional monarchy in the span of only a year, that the 13th-century myth of the Kamikaze became 20th-century reality (Hellyer and Fuess 1). As pressure from foreign powers increased, Japan needed not only to rapidly create a conscript, westernized army able to defend its sovereignty but also to hastily construct an entirely new national identity to unite its people as the old social hierarchy crumbled with its feudal past. Wanting to learn from their Western adversaries, the Japanese leadership sought inspiration for their new national identity from the British Empire, then the most powerful and largest Empire in the civilized world. At that time, it was widely believed that "virtues of gentlemanship and chivalry were the secret behind the empire's strength and prosperity"; that is, the concept of chivalry and its links to medieval knighthood "served as an anchor [for the British Empire] in a rapidly changing" and ethnically diverse world (Benesch, "The Samurai Next Door" 133). This model, which seems to have withstood the test of time, garnered interest not only from Japan, but also from Germany and the United States which noted the effectiveness of such an unified national ideology (Ibid). The modern concept of Bushido owes as much to foreign inspiration as Japanese tradition.

To emulate the British model while conforming to Japan's modernizing trends, the Emperor's cabinet decided to start on a clean slate, adopting the term Bushido as an embodiment of this new ideology. Since this term was rarely used before 1895 and considered a literary relic by many, the new administration had significant leeway to adjust its meaning in order to bolster their narrative (Benesch, "Bushido" 55). The Japanese replaced the chivalrous knights that anchored and embodied Britain's ideology with their equivalent, the Samurai (or Bushi), feudal Japan's elite warriors known for their bravery and undying loyalty to their emperor (Benesch, "The Samurai Next Door" 132). However, the Japanese tended to view chivalric values as insufficiently warlike for their purposes - the influential philosopher Tetsujiro Inoue described them as the "woman worship[ping]" chivalry of the Europeans (Ibid 135). To update chivalry for a more modern, Japanese application, Japan also incorporated the Western theory of Social Darwinism, the idea that only the strongest countries would survive the cutthroat competition among modern nations, into its Bushido virtues. The resulting notion of Japanese superiority reached its apex in 1895 during the Sino-Japanese War when the westernized and modernized conscript army of Imperial Japan easily triumphed over the antiquated Chinese army (Paine 192). Not only did this victory encourage Japan's imperial ambitions overseas, but it also dramatically shifted the focus of Bushido from the virtues of patriotic nationalism, diligence, and duty to one of fanatical nationalism and anti-foreign sentiment (Benesch, The Samurai Next Door 134). This subsequent radical shift in ideology was forced 
by the "Triple Intervention" of Russia, Germany, and France, which compelled Japan to give up many militarily and economically strategic locations gained from their conquests in China that same year. Combined with the criticism of the initial heavy-handedness of France, Belgium, and the U.S at the beginning of the Meiji Restoration, Gashin Shōtan movements, which promoted "hard work for the future of revenge," became extremely popular (Bamba 35). Soon enough, Japan's Social Darwinist values, hatred of Western countries, and an ever-growing loyalty to the emperor, amplified by the indoctrination of Bushido values among the citizenry, became common themes in literature, politics, sports, and especially the military, where the Generals, who came from traditional Samurai backgrounds, quickly adopted this ideology idolizing their class.

\section{Field-Testing Kamikaze-like Tactics and the Bushido Code - The Russo-Japanese War (1904-} 1905)

The Russo-Japanese War (1904-1905), especially during the Siege of Port Arthur, was when the reinstated Bushido values and the concept of Gashin Shōtan emerged in force. After negotiations concerning the balance of power between the Russian and Japanese Empires in Northeastern Asia broke down, the Japanese military intended to surprise the Russian fleet based at the strategically important Port Arthur, now known as Lushun, China (Bunting). With the Russian fleet blockaded in the harbor by Admiral Togo Heihachiro and despite heavy losses on both sides, the Japanese managed to land their ground forces in May 1904 to besiege the port and force a Russian surrender (Connaughton 61). The initial Japanese forces numbered 65,000 men, equating to more than a quarter of the entire Japanese land forces at the time (Ibid 241). During the siege, Japanese commanders noticed the strategic importance of a certain hill (nicknamed 203 Meter Hill), which offered a full view of the harbor, enabling the Japanese forces to fire on the Russians at will (Skey 299). To capture this hill, the Japanese General Nogi Maresuke launched a series of humanwave attacks, with the first attempt causing over 2,500 Japanese deaths without gaining a foothold, thanks to advanced Russian defenses such as powerful artillery and machine guns, which caused havoc among the Japanese forces (Connaughton 232). This banzai charge, as mentioned before, was the land-based equivalent of Kamikaze aerial assaults. Despite the disastrous first attempt, General Nogi launched a second Banzai attack on 203 Meter Hill and other forts October 29, 1904, with limited success, only capturing some minor fortifications but costing the lives of 124 Japanese officers and 3,611 soldiers (Ibid 240). While the Japanese still managed to win the war, with the Russians surrendering on January 2nd, 1905, the Banzai charges did little to help turn the tide of the Russo-Japanese War. In the war's aftermath, however, Banzai charges rose to prominence in Japanese military doctrine and manuals.

To comprehend why Japan would rely on suicidal human-wave attacks to take down heavily fortified positions bristling with automatic weapons and why those tactics rose to prominence in Japanese military doctrine despite their ineffectiveness, it is helpful to understand that the General who captured Port Arthur, Count Nogi Maresuke, had already earned a reputation for relying on suicide attacks and Bushido values from his days as a Major during the Satsuma Rebellion (1877) when his unit lost its regimental banner (Bargen 45). Despite numerous banzai attacks attempting to recapture it, he failed and sought permission from the Emperor to commit ritual suicide to atone for the shame of losing of his regimental banner, which the Emperor denied, strengthening Nogi's sense of indebtedness to the emperor (Nejime 152; Bargen 2). Nogi continued the same behavior after the Russo-Japanese war, when he again asked for permission to commit ritual suicide in response to mounting criticism from the Japanese government over the number of troops that he lost. The Emperor nevertheless defended Nogi's actions, hailed him as a national hero, leading many to use his leadership to embody "the great strength of Bushido of . . Japan" (Benesch, Inventing the Way of the Samurai 154). Many viewed Nogi as representing the "best of the Japanese Samurai tradition," an invaluable trait when the Meiji Restoration had just implemented the Bushido code into Japanese society (Storry 217). Kamikaze-like attacks became prominent in field manuals because, even though the high brass of the Japanese army acknowledged the obsolescence of these suicide tactics, "few field commanders who served in this war were left unimpressed by the willingness of their troops to engage in human-bullet attacks" (Steinberg 197-198). The World War Two Admiral Matome Ugaki also stressed the importance of an army's readiness "to charge into the jaws of 
death," a spirit of self-sacrifice which would soon prove valuable for Japanese commanders (Ibid 198). The rightleaning Japanese government saw the value of a nation of citizen-soldiers willing to sacrifice their lives during the Battle of Port Arthur and began to champion this example as a characteristic of the Bushido code, which highlighted courage, benevolence, and loyalty (Clark). Accordingly, the corrupt government exploited the growing support for Banzai charges and the Bushido ideals that they popularized to distract the citizenry from its incompetence, while also revising the Japanese infantry field manuals to stress the importance of Arme Blanche combat, or close combat using swords but not firearms (Kublin 329). The rash decisions of one general and the surprising willingness of Japan to adopt his failed Banzai Charges as models for soldiers in future combat was an important building block towards Japan's ultimate actions in World War Two.

\section{The Revival of Kamikaze Tactics in World War Two}

The aforementioned wars, policy changes and their subsequent influences on Japanese society and military doctrine ultimately reached their pinnacle in the final years of World War Two. At the beginning of the war, the Japanese had little to no reason to utilize kamikaze attacks as they arguably held tactical superiority. On December 8 , when the United States declared war on Japan, the Imperial Japanese Navy possessed a total of ten aircraft carriers compared to America's six, making it the world's third most powerful navy at that time (Stille 8). The U.S. Pacific Fleet, on the other hand, had just been devastated by the Pearl Harbor attack, and America's allies, the British and their Royal Navy, had been driven from Southeastern Asia as a result of a series of Japanese attacks (Peattie172). In addition to dominating the seas, the Japanese were also able to project power on land as well, due in part to the 1.7 million manstrong ground force already stationed in Mainland Asia (Jowett and Andrew 7). The deadly combination of land and sea power is especially apparent when examining Japan's conquests during that time. In a single year, they captured Malaya, Singapore, and the Philippines, from where American General Douglas MacArthur was forced to make his infamous retreat by boat ("Pacific War"; "General MacArthur Leaves Corregidor"). This period of time was so successful that it was known as "the invincible years" for Japan. However, after the Battle of Midway, where the outnumbered U.S. Pacific Fleet, having sunk four Japanese aircraft carriers and a cruiser, defeated the Imperial Japanese Navy and halted their advances in the Pacific, forced the Japanese to suspend the planned invasions of Fiji and Samoa because of the loss of most of their best-trained pilots and thus their ability to project air power ("The Battle of Midway”). Their loss at Midway, compounded with another Japanese defeat at the Battle of Guadalcanal and the ensuing U.S. island-hopping campaign, compelled the Japanese to go on the defensive ("The Solomon Islands Campaign: Guadalcanal"). By this point, the tiny island nation could do little against the industrial might of the combined Allied Forces, especially with its loss at Guadalcanal draining its already-dwindling oil supply and its shipping routes under constant harassment from Allied submarines, hurting its economy and disrupting the army's supply chain (Miller 490). What's more, the U.S. Air Force's new Hellcats, Corsairs, and advanced radar technologies overwhelmed and rendered obsolete the previously superior Zero fighter planes utilized by the Japanese air force (Lorell and Levaux 21). With the odds decidedly against Japan, the Empire made its last stand defending the Japanese home islands in the Philippines.

The man whom Japan put in charge of the seemingly impossible task of halting the U.S. air offensive in the Philippines was Vice-Admiral Takijirō Ōnishi, whom many credit as the father of the modern Kamikaze. By the time he took command of the 1st Air Wing in the Northern Philippines, he had fewer than forty operational planes on hand (Young and Styling 9). Acknowledging the near impossibility of his mission, he observed: "In my opinion, there is only one way of assuring that our meagre strength will be effective to a maximum degree. That is to organize suicide attack units composed of Zero fighters armed with 250-kilogram bombs, with each plane to crash-dive into an enemy carrier" (Stern 57). Ōnishi followed through with his words and created the first kamikaze unit, comprised wholly of "volunteers" (Hattori 17). Even though each pilot had technically volunteered for the suicide mission, letters written to loved ones reveal a story that counters the Japanese propaganda at the time (Ibid). Lieutenant Seki, the leader of this unit, recounted that "Japan's future is bleak if it is forced to kill one of its best pilots" (Axell and Kase 16). The 
pressure on Japanese soldiers, especially commissioned officers, to conform to the Bushido warrior values triumphed by propaganda, including selfless loyalty to the Emperor, was immense and compelled many young Japanese men to "volunteer" for these missions to defend their families' honor, a value stressed by Bushido (Benesch, "The Samurai Next Door" 143; Powers).

Despite massive kamikaze attacks ordered by the Japanese high command, including the surprise attack on Okinawa mentioned at the beginning of this essay, Kamikaze attacks throughout the Pacific Campaign failed to achieve anything significant. Richard P. Hallion, Senior Advisor of Air and Space Affairs for the Pentagon, estimates that of the 4,800 Japanese aircraft used in Kamikaze attacks, only "14 percent . . survived to score a hit on a ship [and only] 8.5 percent of all ships hit by Kamikaze sank," equating to only 57 ships throughout the entire Pacific Campaign (Hallion; Gordon). Despite the poor strategic returns on Kamikaze attacks, Japan's Naval Air Headquarters decided to proceed with the idea of purpose-built "manned missiles," or Ohka, proposed by one of its ensigns in August 1944 (Johnsen 15). By this time, the tide had already turned overwhelmingly in favor of the Americans, as Japan's Prime Minister Hideki Tojo, a chief instigator of Japan's involvement in World War Two, had resigned, and the American forces had already won the Battle of the Philippine Sea, destroying an additional three Japanese carriers in the process (Kingston; "Battle of the Philippine Sea"). Sheer hopelessness drove the Japanese top brass to adopt the Ohka as their final option to protect Japan from imminent invasion, with Commander Masao Yamana, one of the key figures in the development of the Ohka, saying: "Before this is over, we too will have to take a dive in that plane" (Momiyama 7). Some of the requirements for the Ohka put in place by the Japanese military perfectly depict the desperation of the Japanese: requirements such as it needing to "be extremely small for ease of assembly and storage in narrow underground bunkers" respond to the constant bombardment from American B-29s on the Japanese mainland while others, such as the requirements to "be manufactured from easily obtainable materials [and the need of the Ohka to] be of simple design for easy manufacturing in one-tenth the time required for a normal fighter," underscores the incredible shortage of manpower and raw materials available in Japan (Ibid 8). In other words, the adoption of the Ohka represented a desperate attempt by the Imperial Japanese Air Force to create a viable defensive weapon with limited resources rather than a groundbreaking answer to the relentless American offensives.

\section{Conclusion}

Given its late development, the Ohka was only ever used during the Okinawa campaign, where it managed to sink just one ship ("Yokosuka MXY-7 Ohka (Baka Bombs)"). Japan surrendered unconditionally within four months of this battle because of the atomic bombings of Hiroshima and Nagasaki and, with that, came the wave of ritual suicides by Japanese officers deeply invested in the Bushido code (Judge 82). They used this seppuku to "avoid the dishonor of falling into the hands of the enemy" (in this case, the American forces) ("Seppuku"). Many of Japan's top military brass, including Admiral Ōnishi, the "father of Kamikaze," and Korechika Anami, the Minister of War, ended up dying in this way (Momiyama 12; Frank 319-320). These suicides demonstrate just how invested the Japanese military, and particularly its top brass, was in the Bushido codes and how willfully blind the Japanese generals were to their imminent defeat in World War Two, choosing instead to rely on desperate, last-ditch military campaigns and suicide tactics to halt the American advance instead of accepting the inevitable. However, the generals were not entirely to blame. For decades, thanks to the Meiji restoration and its continuing propaganda highlighting nationalist values, from the belief that "God is on our side" during the 13th-century Mongolian invasions to the faith in the suicidal but useless Banzai charges in the Russo-Japanese War, many officers from conservative backgrounds were essentially brainwashed into adopting the Bushido code as sacred, and these values in turn heavily influenced their decision-making during Japan's many wars. Kamikaze warfare resulted from the outgrowth of 900 years of legendary ideology centered around fanatical self-sacrifice, modified in modern times by a 50 -year campaign to radicalize a fanatical nationalist identity in response to Western military rivals. Therefore, a series of major turning points in Japan's history, and not just a few rash decisions made by some Japanese generals in World War Two, led to the overreliance on the Kamikaze during the last few years of the war. 
Ironically, a propagandistic faith in a supposed divine intervention that justified Japan's Kamikaze tactics doomed the very nation they were intended to protect. Due to intercepted communications, which revealed that "up to 2,000 obsolete planes and trainers were being assigned . . . for kamikaze missions," the Office of Strategic Services (The Central Intelligence Agency's precursor) estimated the capture of Kyushu alone, one of Japan's five main islands, would have incurred American casualties "significantly more than double the Okinawa level," which numbered over 49,000 men (MacEachin). As a result, the U.S. estimated that taking the entirety of Japan would have cost well over one million American casualties (Stimson 8). Consequently, Secretary of War Henry Stimson stressed the importance of obtaining a Japanese surrender without the high casualties on both sides, no small part of which would be attributed to further kamikaze attacks (Ibid). Essentially, the fear of further fanatical kamikaze and other kinds of suicide attacks compelled the U.S. to deploy the atomic bomb as its last resort.

\section{Acknowledgements}

I would like to offer my deep appreciation to Dr. Andrew R. Wilson for his valuable for his valuable feedback during the research process as well as the formatting step of this paper.

\section{References:}

Adams, Ryon F. “Outfought and Outthought: Reassessing the Mongol Invasions of Japan.” U.S. Army Command and General Staff College, 12 June 2009.

Axell, Albert, and Hideaki Kase. Kamikaze: Japan's Suicide Gods. Pearson, 2002.

Bargen, Doris G. Suicidal Honor General Nogi and the Writings of Mori Ogai and Natsume Soseki. University of Hawai ‘i Press, 2006.

"The Battle of Midway: Turning the Tide in the Pacific." Encyclopadia Britannica, Encyclopædia Britannica, Inc., 4 June 2012, blogs.britannica.com/2012/06/the-battle-of-midway-turning-the-tide-in-the-pacific/.

"Battle of Okinawa." History.com, A\&E Television Networks, 29 Oct. 2009, www.history.com/topics/world-war-ii/battle-of-okinawa.

"Battle of the Philippine Sea." Encyclopaedia Britannica, Encyclopædia Britannica, Inc., 20 July 1998, www.britannica.com/event/Battle-of-the-Philippine-Sea.

Benesch, Oleg. "Bushido: The Creation of a Martial Ethic in Late Meiji Japan.” University of British Columbia, 2011, pp. 50-55.

Benesch, Oleg. Inventing the Way of the Samurai: Nationalism, Internationalism, and Bushido in Modern Japan. Oxford University Press, 2016.

Benesch, Oleg. "The Samurai Next Door: Chinese Examinations of the Japanese Martial Spirit." Extrême-Orient Extrême-Occident, no. 38, 2014, pp. 129-168., doi:https://www.jstor.org/stable/24716508.

Bunting, Tony. "Battle of Port Arthur.” Encyclopadia Britannica, Encyclopædia Britannica, Inc., 26 Jan. 2020 , www.britannica.com/event/Battle-of-Port-Arthur.

Cartwright, Mark. “The Mongol Invasions of Japan, 1274 \& 1281 CE.” World History Encyclopedia, World History

Encyclopedia, 2 July 2019, www.worldhistory.org/article/1415/the-mongol-invasions-of-japan-1274--1281-ce/.

Clark, Tim. "The Bushido Code: The Eight Virtues of the Samurai.” University of Southern California, 2008.

Connaughton, Richard M. Rising Sun and Tumbling Bear: Russia's War with Japan. Cassell Military, 2004.

Cox, Samuel J. "H-039-4: First Kaiten Attack." Naval History and Heritage Command, Department of Defense,

Dec. 2019, www.history.navy.mil/about-us/leadership/director/directors-corner/h-grams/h-gram-039.html.

Delgado, James P. "Relics of the Kamikaze.” Archaeology, vol. 56, no. 1, 2003, pp. 36-41., doi:https://www.jstor.org/stable/41779114. 
Frank, Richard B. Downfall: The End of the Imperial Japanese Empire. Penguin , 2011.

Garfield, Brian. Thousand-Mile War: World War II in Alaska and the Aleutians. University of Alaska Press, 2010.

“General MacArthur Leaves Corregidor.” History.com, A\&E Television Networks, 21 July 2010, www.his-

tory.com/this-day-in-history/macarthur-leaves-corregidor.

Gill, G. Hermon. Royal Australian Navy. Collins in Association with the Australian War Memorial, 1985.

Gnam, Carl. "Hanna Reitsch, the Reichenberg Project \& Germany's Kamikazes." Warfare History Network, Sovereign Media, 4 June 2020, warfarehistorynetwork.com/2016/09/06/hanna-reitsch-the-reichenberg-project-germanyskamikazes/.

Gordon, Bill. “Https://Wgordon.web.wesleyan.edu/Kamikaze/Background/Ships-Sunk/Index.htm.” 47 Ships Sunk by Kamikaze Aircraft, Wesleyan University, wgordon.web.wesleyan.edu/kamikaze/background/ships-sunk/index.htm.

Hallion, Richard P. "Precision Weapons, Power Projection, and the Revolution in Military Affairs." Air Force Historical Studies Office, 26 May 1999.

Hattori, Syohgo. “Kamikaze: Japan's Glorious Failure.” Air Power History, vol. 43, no. 1, 1996, pp. 14-27., doi:https://www.jstor.org/stable/26287970.

Hellyer, Robert I., and Harald Fuess. The Meiji Restoration: Japan as a Global Nation. Cambridge University Press, 2020.

Holloway, April. "Kamikaze - The Divine Winds That Saved Japa.” Ancient Origins, Stella Novus, 4 Nov. 2014, www.ancient-origins.net/ancient-places-asia-history-important-events/kamikaze-divine-winds-saved-japan-001995.

"John Chapman and the Kamikaze Attack." PBS, Public Broadcasting Service, www.pbs.org/wgbh/americanexperience/features/pacific-john-chapman/.

Johnsen, Frederick A. Testbeds, Motherships and Parasites. Specialty Press, 2018.

Jowett, Philip, and Stephen Andrew. The Japanese Army 1931 - 45. Osprey Publishing, 2002.

Judge, Sean M. “Who Has the Puck?”: Strategic Initiative in Modern, Conventional War. Air University Press, 2009.

Kingston, Jeff. "Battle of Saipan: Beginning of the End.” The Japan Times, 7 July 2014, www.japan-

times.co.jp/news/2014/07/05/national/history/battle-saipan-beginning-end/.

Kublin, Hyman. "The Japanese Socialists and the Russo-Japanese War.” The Journal of Modern History, vol. 22, no. 4, 1950, pp. 322-339., doi:https://www.jstor.org/stable/1875893.

Lorell, Mark A., and Hugh P. Levaux. The Cutting Edge: A Half Century of U.S. Fighter Aircraft R\&D. RAND, 1998.

MacEachin, Douglas J. The Final Months of the War with Japan: Signals Intelligence, US Invasion Planning, and the A-Bomb Decision. Center for the Study of Intelligence, 1998.

Miller, Nathan. War at Sea: A Naval History of World War II. Oxford University Press, 1996.

Momiyama, Thomas S. "Racing Against Invasion: Engineering a Kamikaze 'Cruise Missile." Air Power History, vol. 56, no. 2, 2009, pp. 4-13., doi:https://www.jstor.org/stable/26275748.

Nejime, Kenichi. "Suicide and Its Meaning in History: Rethinking Francesco Carletti and Japanese Writers.” Bulliten of Gakushuin Women's University, 2017.

Neumann, Jehuda. "Great Historical Events That Were Significantly Affected by the Weather: I. the Mongol Invasions of Japan.” Bulletin of the American Meteorological Society, vol. 56, no. 11, 1975, pp. 1167-1171., doi:https://www.jstor.org/stable/26216307.

“Pacific War.” Encyclopaedia Britannica, Encyclopædia Britannica, Inc., 29 Apr. 2017, www.britannica.com/topic/Pacific-War.

Paine, Sarah C. The Sino-Japanese War of 1894-1895 Perceptions, Power, and Primacy. Cambridge University Press, 2009.

Peattie, Mark R. Sunburst: The Rise of Japanese Naval Air Power, 1909-1941. Osprey, 2014. 
Powell, Devin. “Japan's Kamikaze Winds, the Stuff of Legend, May Have Been Real.” National Geographic, National Geographic Partners, 16 May 2016, www.nationalgeographic.com/science/article/141104-kamikaze-kublai-khanwinds-typhoon-japan-invasion.

Powers, David. "History - World Wars: Japan: No Surrender in World War Two.” BBC, 17 Feb. 2011, www.bbc.co.uk/history/worldwars/wwtwo/japan no surrender 01.shtml.

Quinlivan, James T. "Ramming in the Soviet Air Force." Air Power History, vol. 36, no. 1, 1989, pp. 48-56., doi:https://www.jstor.org/stable/26271265.

“Seppuku.” Encyclopæedia Britannica, Encyclopædia Britannica, Inc., 21 July 1998, www.britannica.com/topic/seppuku.

Skey, F. E. G. "The Final Struggle for 203-Meter Hill at Port Arthur." Professional Memoirs, Corps of Engineers, United States Army, vol. 3, no. 10, 1911, pp. 276-301., doi:https://www.jstor.org/stable/44534879.

"The Solomon Islands Campaign: Guadalcanal: The National WWII Museum: New Orleans." The National WWII Museum | New Orleans, The National World War II Museum, 10 July 2017, www.nationalww2museum.org/war/articles/solomon-islands-campaign-guadalcanal.

Steinberg, John W. The Russo-Japanese War in Global Perspective: World War Zero. Brill, 2005.

Stern, Robert C. Fire from the Sky: Surviving the Kamikaze Threat. Naval Institute Press, 2010.

Stille, Mark E. The Imperial Japanese Navy in the Pacific War. Osprey Publishing Co., 2014.

Stimson, Henry L. "The Decision to Use the Atomic Bomb." SAIS Review, vol. 5, no. 2, 1985, pp. 1-15., doi:10.1353/sais.1985.0040.

Storry, Richard. A History of Modern Japan. Penguin, 1960.

Turnbull, Stephen R., and Richard Hook. The Mongol Invasions of Japan. Osprey Publishing, 2013.

Turnbull, Stephen R. Genghis Khan \& the Mongol Conquests. Routledge, 2003.

"Yokosuka MXY-7 Ohka (Baka Bombs)." National Museum of the U.S. Navy, Department of the Navy, www.history.navy.mil/content/history/museums/nmusn/explore/photography/wwii/wwii-pacific/oki-nawa/yokosuka-mxy-7-ohka.html.

"Yokosuka MXY-7 Ohka 11." Yanks Air Museum, 2013, yanksair.org/collection/yokosuka-mxy-7-ohka-11/. Young, Edward M., and Mark Styling. American Aces against the Kamikaze. Osprey Publishing, 2013. 